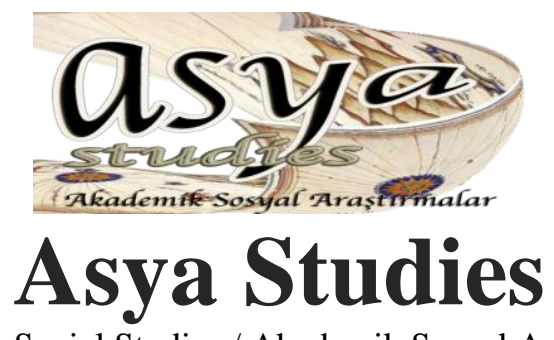

Academic Social Studies / Akademik Sosyal Araştırmalar

Year: 5 - Number: 18, p. 21-41, Winter 2021

\title{
Ortaokul Matematik Öğretmeni Adaylarının Matematik ve Matematik Öğretmeni Algıları: Metaforik Bir Yaklaşım**
}

The Perceptions of Pre-Service Middle School Mathematics Teachers Regarding Mathematics and Mathematics Teacher: A Metaphorical Approach

DOI: https://doi.org/10.31455/asya.940207

Araştırma Makalesi / Research Article

Makale Geliş Tarihi / Article Arrival Date 20.05.2021

Makale Kabul Tarihi / Article Accepted Date

17.12.2021

Makale Yayın Tarihi / Article Publication Date 31.12.2021

\section{Asya Studies}

Doç. Dr. Yasemin Katrancı Kocaeli Üniversitesi, Eğitim Fakültesi, Matematik ve Fen Bilimleri Eğitimi Bölümü,

yasemin.katranci@kocaeli.edu.tr ORCID ID

https://orcid.org/0000-0002-0916-2407

Arş. Gör. Büşra Kıral

İstanbul Aydın Üniversitesi, Eğitim

Fakültesi, Matematik ve Fen Bilimleri Eğitimi Bölümü,

busrakiral@aydin.edu.tr ORCID ID

https://orcid.org/0000-0001-5816-6183

* “COPE-Dergi Editörleri İçin Davranış Kuralları ve En İyi Uygulama İlkeleri" beyanları: Bu çalıșma için herhangi bir çıkar çatıșması bildirilmemiştir. Bu araştırmada 2020 yılı öncesi verileri kullanılmıştır. Makale, dergiye 2021 yılında gönderilmiştir. $\mathrm{Bu}$ sebeple geçmişe yönelik Etik Kurul Onayı alınamamıs ve bu durum makale içnde ULAKBIM TR DİİN kararına uygun şekilde "Etik Kurul Onay Bilgileri” bölümünde açiklanmıștır.

* Bu çalıșma, "14. Ulusal Fen Bilimleri ve Matematik Koğitimi Kongresi (UFBMEK2021)"nde sözlü bildiri olarak sunulmuştur.
$\ddot{O} z$

$\mathrm{Bu}$ araştırmada ortaokul matematik ögretmeni adaylarının matematik ve matematik öğretmeni kavramlarına yönelik algılarının belirlenmesi amaçlanmıştır. Araştırmanın amacı doğrultusunda bilgi ve duyular arasında köprü görevi gören metaforların kullanılmasına karar verilmiştir. Araştırma betimsel nitelikte olup, katılımcılar uygun örneklemeye göre belirlenmiştir. $\mathrm{Bu}$ kapsamda araştırmanın çalışma grubu 59 ortaokul matematik öğretmeni adayından oluşmaktadır. Araştırmanın verileri; "Matematik, .......... gibidir; çünkü .........." ve "Matematik ögretmeni, ......... gibidir; çünkü .........." cümlelerinin katılımcılar tarafından tamamlanması ile elde edilmiştir. Verilerin analizinde ve yorumlanmasında; i) adlandırma, ii) eleme, iii) kategori ve iv) geçerlik-güvenirlik sağlama aşamaları takip edilmiştir. Sonuç olarak matematik, en çok bina, puzzle ve su metaforları ile ifade edilmiştir. Bu metaforlar, ortaokul matematik öğretmeni adaylarının matematiği; "evrendeki parçaları birleştirerek ihtiyacımız olan yapıları inşa etmek" olarak algıladıklarını ortaya koymuştur. Matematik öğretmeni kavramı ise en çok bahçıvan, pusula ve güneş metaforları ile belirtilmiştir. Bu metaforlar, ortaokul matematik öğretmeni adaylarının matematik öğretmenini; "ögrencilerini iyi bir şekilde tanıyarak öğretim yapan ve onları aydınlatan bir yol gösterici” olarak algıladıklarını göstermiştir. Matematiğin temellerinin ilkokul yıllarında atıldığı göz önüne alındığında, bu çalışmaya benzer bir çalışmanın sınıf öğretmeni adayları ile gerçekleştirilmesi ve onların bu kavramlara yönelik algılarının ortaya konması önerilmektedir. Böylece eğer var ise olumsuz algıları ortadan kaldırmaya yönelik çalışmalar yapılabilir. Ayrıca öğrencilerin matematiği ve matematik öğretmenini algılayış biçimleri ilkokuldan itibaren araştırılarak matematiğe yönelik bakış açıları belirlenebilir.

Anahtar Kelimeler: Metafor, Matematik, Matematik Öğretmeni, Öğretmen Adayı

\section{Abstract}

In this study, it was aimed to determine the perceptions of pre-service middle school mathematics teachers regarding mathematics and mathematics teacher. In order to achieve this goal, it was decided to use metaphors that act as a bridge between knowledge and senses. Participants in this descriptive study were determined according to convenience sampling. In this context, 59 pre-service middle school mathematics teachers participated in the study. Data for the study was collected by using these two sentences; "Maths is like, ..........; because ..........." and "Mathematics teacher is like, ..........; because .........." The data was obtained by filling out the sentences by the pre-service teachers. In the analysis and interpretation of the data; i) naming, ii) elimination, iii) category, and iv) validity-reliability stages were followed. As a result, mathematics is mostly expressed with the metaphors of building, puzzle, and water. These metaphors show that mathematics is defined as "building the structures we need by combining the parts in the universe" by pre-service teachers. The concept of mathematics teacher was mostly stated with the metaphors of gardener, compass, and sun. These metaphors express that mathematics teacher is defined as "a guide who teaches by knowing their students well and enlightens them" by pre-service teachers. Considering that the foundations of mathematics were laid in the primary school years, it could be suggested that a study similar to this study should be carried out with pre-service classroom teachers and their perceptions of these concepts should be revealed. Thus, efforts could be made to eliminate negative perceptions, if any. In addition, students' perception of mathematics and mathematics teacher could be investigated starting from primary school and their perspective towards mathematics could be revealed.

Keywords: Metaphor, Mathematics, Mathematics Teacher, Pre-service Teacher

\section{Citation Information/Kaynakça Bilgisi}

Katrancı, Y. ve Kıral, B. (2021). Ortaokul Matematik Öğretmeni Adaylarının Matematik ve Matematik Öğretmeni Algıları: Metaforik Bir Yaklaşım. Asya Studies-Academic Social Studies / Akademik Sosyal Araştırmalar, 5(18), 21-41. 


\section{GİRIS}

Matematik her şeydedir, matematiksiz hayat olmaz, matematik hayatımızın her alanındadır gibi çeşitli söylemler yaygın olsa da matematiğin aslında ne ifade ettiği merak edilmektedir. Bu meraktan yola çıkılarak matematiğin ne olduğu sorusunun cevabı araştırıldığında; cebir, aritmetik ve geometri gibi sayı ve ölçü temeline dayanan, niceliklerin özelliklerini inceleyen bilimlerin ortak adıdır (Türk Dil Kurumu [TDK], 2021a) şeklinde bir cevap ile karşılaşılmaktadır. Bunun yanı sıra Umay (2002) matematiği, tanımlanması en zor kavramlardan biri olarak ifade etmektedir. Bunun nedenini de matematiğin ele avuca sı ̆̆maz yapısının yanı sıra herkes tarafından biraz çekinilen bir tarafının olması olarak görmektedir. Matematiği tanımlamanın sadece onun belli özelliklerini sıralamak olduğunu da belirtmektedir. Halmos (1980) ise matematik gerçekten ne içermektedir: Aksiyomlar mı, teoremler mi, kanıtlar mı, yoksa kavramlar $\mathrm{m} ı$ şeklinde sormuş ve matematiğin elbette bunlarsız var olamayacağını belirtmiştir. TDK (2021a) tarafından verilen tanım incelendiğinde de bu durum göze çarpmaktadır.

Matematik, sayısal alanlar için temeldir ve ülkelerin bu alanda yetişmiş işgücünü doğrudan etkileyen bir bilim olarak görülmektedir. Bu sebeple de ülkeler matematik alanında iyi yetişmiş bireylere ihtiyaç duymaktadır. Ne var ki soyut yapısıyla matematik dersinde öğrenciler bir hayli zorlanmaktadır (Dede ve Argün, 2004). Bununla birlikte öğrenciler matematiği, ilkokuldan üniversiteye kadar sıkıcı, zor ve sevilmeyen bir ders olarak değerlendirmektedirler (Uçar, Pişkin, Akkaş ve Taşçı, 2010; Yetim-Karaca ve Ada, 2018). Öğrencilerin bu düşüncelerini etkileyen etmenler göz önüne alındığında ise öğretmenlerin bu faktörler arasında önemli bir yer teşkil ettiği göze çarpmaktadır. Öğrencilerin matematiğe karşı inançları, duyguları, olumlu ve olumsuz tutumlarının, onların matematik öğretmenleri tarafından etkilendiği de bilinmektedir (Akdemir, 2006; Çekici ve Yıldırım, 2011; Uçar vd. 2010).

Herhangi bir şeye karşı negatif tutuma veya algıya sahip olunması, onu olumsuz olarak aktarmayı içermektedir. Nitekim Çalışıcı ve Özçakır-Sümen (2019), matematiği sevmeyen bir öğretmenin, öğrencilerine onu sevdirmesinin düşünülemeyeceğini belirtmiş ve ondan matematikte başarılı öğrenciler yetiştirmesinin beklenemeyeceğini ifade etmişlerdir. Ayrıca öğrencilerin matematik ile ilgili algılarını öğretmenlerin büyük oranda etkilediğini ve öğrencilerin matematiğe yönelik olumlu algılara sahip olabilmeleri için ilk olarak öğretmenlerin olumlu algılara sahip olmaları gerektiğini eklemişlerdir. Matematik öğretmenleri, öğrenciler üzerindeki bu etkilerin farkında olarak öğrencilerin matematiğe karşı olumlu düşünce ve tutumlara sahip olmaları için çabalamalıdırlar (Şahin, 2013; Uçar vd. 2010). Bu çabanın oluşabilmesi için ilk olarak matematik öğretmenlerinin ne tür algı veya düşüncelere sahip olduklarının belirlenmesinin önemli olduğu düşünülmektedir. Bu belirlemeye de henüz mesleğe başlamadan, öğretmen adayı iken başlanılmasının eğer var ise olumsuz algıların ortadan kaldırılmasında önemli olacağı ön görülmektedir. Çünkü var olan olumsuz algıların mesleğe başlamadan ortadan kaldırılması için çalışmalar yapılabileceği gibi bu olumsuz alg1 ve düşüncelerin kaynakları da araştırılabilir. Ayrıca olumsuzlukların da aktarılarak devam etmesinin önüne geçilmiş olunacağı düşünülmektedir. Öyle ki Noyes (2004) tarafindan da öğretmen adayları ve öğretmenlerin, alg1, tutum, inanç ve eğilim gibi özeliklerinin belirlenmesi, öğretmen eğitimi çalışmalarının temel amaçlarından biri olarak görülmekte ve öğretmenlerin profesyonel gelişimlerine yardımcı olunması açısından önemli olarak değerlendirilmektedir.

$\mathrm{Bu}$ algı ve düşüncelerin ortaya çıkarılmasının bir yolu metaforları kullanmak olarak görülebilir. Yılmaz, Göçen ve Yılmaz (2013) da çalışmalarında metaforların, öğretmen adaylarının mesleklerine yönelik algılarını açığa çıkarmada, anlamada ve açıklamada güçlü birer araştırma aracı olarak kullanılabileceğini ifade etmişlerdir. İnsan anlayışının bir şekli veya sadece bir söz biçimi olmayıp aynı zamanda bir düşünce figürü olan metaforlar, deneyimlerin boyutlarını tutarlı kılan ve vurgulayan yapısı ile gelecekteki eylemlerimiz için kılavuzluk edebilirler (Lakoff ve Johnson, 2005). Metafor, mecaz (TDK, 2021b) olarak belirtilmektedir. Forcenville (2002) ise metaforu, kişinin bir olgu veya kavramı algıladığ şekilde, benzetmelerle ifade etmesi olarak açıklamaktadır. Aristo'ya (2008) göre ise bir kelimenin özel anlamının yanı sıra başka bir anlamının verilmesidir. Saban (2004) metaforları, olayların oluş ve işleyiş 
süreci ile ilgili düşüncelerimizi yapılandırarak yönlendiren güçlü zihinsel araçlar olarak belirtmektedir. Ayrıca metaforların, iki şey arasında karşılaştırma yapılmasına, bu iki şey arasındaki benzerliklerin ortaya konmasına veya bir şeyin başka bir şey yerine konarak açıklanmasına yardımcı olduğunu ifade etmektedir. Metaforlar; soyut kavramların nasıl algılandığını ortaya koymaya yarayan somut kavramlar olup soyut özelliklerin bilinen diğer şeylerle açıklanmasıdır (Perry ve Cooper, 2001; Şahin, 2013). Yılmaz ve Altıntaş (2018) da soyut kavramların somutlaştırılmasında metaforların son derece önemli olduğuna odaklanmaktadırlar. Bu durumu Çelik ve Çakır (2015), bilinçli veya bilinçsiz olarak öğretmenlerin, soyut kavramları ifade etmede metaforları kullandığını belirterek açıklamaktadırlar. Bu araştırmada da soyut bir kavram olan matematik, matematik öğretmeni adaylarına göre ele alınmıştır. Bu yönüyle de araştırmada metaforların kullanımı uygun bulunmuştur.

İlgili alan yazında, ortaokul matematik öğretmeni adaylarının (OMÖA) "matematik öğretmeni" (Demirkol ve Ergin, 2017; Güler, Öçal ve Akgün, 2011) ve "matematik” kavramına yönelik (Çalışıcı ve Özçakır-Sümen, 2019; Demirkol ve Ergin, 2017; Erdoğan, Yazlık ve Erdik, 2014; Evren-Yapıcıŏglu ve Korkmaz, 2019; Güner, 2013) algılarını inceleyen araştırmalar yer almaktadır. Örneğin; Demirkol ve Ergin (2017) çalışmalarında, matematik öğretmenliği kavramına ilişkin en çok anne, ağaç ve güneş metaforlarının üretildiği sonucuna ulaşmış ve üretilen metaforların yol gösterici, annelik, yetiştirmek, bilgilendirici ve kabus olmak üzere beş farklı kategoride toplandığını ortaya koymuşlardır. Güler, Öçal ve Akgün (2011) ise çalışmalarında matematik öğretmeni ile ilgili en çok ressam, su, basketbol koçu ve ansiklopedi metaforlarının üretildiğini saptamışlardır. Bunlarla birlikte Çalışıcı ve Özçakır-Sümen (2019) öğretmen adaylarının matematiği en çok hayat ve bulmaca metaforları ile temsil ettiklerini belirlemişlerdir. Demirkol ve Ergin (2017) de matematiğin hayat, bulmaca ve su mateforları ile ifade edildiği ve katılımcıların genel olarak olumlu bir algıya sahip oldukları ve üretilen metaforların ise bağlamsal, sistematik, ihtiyaç, nesne, sembolik sistem ve hayat olmak üzere altı farklı kategoride toplandığı sonuşlarına ulaşmışlardır. Erdoğan, Yazlık ve Erdik (2014) ise matematiğin su, bulmaca, okyanus, deniz ve puzzle metaforları ile ortaya konduğu sonucuna ulaşırken bu metaforların 14 farklı kavramsal kategori altında toplandığını belirlemişlerdir. Evren-Yapıcıoğlu ve Korkmaz (2019) ise matematik kavramına yönelik en çok hayat, güneş ve evren metaforlarının üretildiğini tespit etmişlerdir. Ayrıca matematiğe yönelik farklı kavramsal kategorilerin meydana geldiği sonucuna ulaşmışlardır. Bu ketagoriler; karmaşık ve anlaşılmaz matematik, duruma göre değişen matematik, çaba gerektiren matematik, olumlu duygular uyandıran matematik, sonsuz matematik, hayat/yaşam ile ilişkili matematik, aşamalılık/sistematiklik içeren matematik, korkutucu matematik, evrenin temeli matematik, belirsiz matematik, sayılar ile ilgilenen matematik, süreç olarak matematik ve temellerini doğadan alan matematik şeklindedir. Güner (2013) ise bulmaca, oyun ve hayat metaforlarının üretildiğini belirleyerek matematik öğretmeni adaylarının büyük çoğunluğunun matematiğin hayatın kendisi olduğunu düşündüklerini ifade etmiştir. Bununla birlikte matematiğin; matematik hayatın kendisidir, matematik zevkli bir uğraştır, matematik hayatı kolaylaştırır ve matematik hayatı zorlaştırır kategorileri altında ele alındığını belirlemiştir.

Bunların yanı sıra hem ilköğretim hem de ortaöğretim matematik öğretmeni adaylarının, “matematik” kavramına yönelik algılarının da (Çalışıcı ve Özçakır-Sümen, 2019; Güler, Akgün, Öçal ve Doruk, 2012) incelendiği çalışmalar bulunmaktadır. Çalışıcı ve Özçakır-Sümen (2019) ilköğretim ve ortaöğretim matematik öğretmeni adayları ile birlikte çalışmışlar ve adayların matematik ile ilgili 80 metafor ürettikleri, bu metaforların da 11 kavramsal kategori altında toplandığı sonucuna ulaşmışlardır. Sonuçta; adayların matematiği günlük hayatta ihtiyaç duyulan, uğraşmaktan zevk alınan ve emek gerektiren bir alan olarak gördükleri tespit edilmiştir. Güler vd. (2012) ise matematiği ifade etmek için en çok tekrarlanan metaforların hayat, bulmaca ile su olduğunu belirlemiş ve matematiğin hayatın değişmez bir parçası olduğu sonucuna ulaşmışlardır. Ayrıca öğretmen adayları tarafından matematiğin, yol gösterici, gereksinim, bakış açısı, sonsuzluk ve hayatın kendisi kavramsal kategorileriyle açıklandığı sonucunu elde etmişlerdir. 
Matematik öğretmeni adaylarının matematiğe yönelik tutumları ile metafor algılarının da araştırıldığı (Brady ve Winn, 2014; Kuzu, Kuzu ve Sıvac1, 2018) görülmüştür. Brady ve Winn (2014), matematiğin genel olarak yapı, yetenek, araç, puzzle, oyun ve spor metaforları ile ifade edildiği sonucunu elde etmişlerdir. Ayrıca matematik ile ilgili üç farklı kavramsal kategori (duygusal eğilim, matematik vizyonu ve algılanan yetkinlik) ve bunların alt kategorilerine ulaşmışlardır. Kuzu vd. (2018) ise çalışmalarında, öğretmen adayları tarafından matematiğin temel ihtiyaç olarak algılandığını saptamışlardır. Ayrıca matematik kavramına yönelik metaforların; temel ihtiyaç, duygu, eğlence ve sorun şeklinde dört farklı kavramsal kategoriye ayrıldığı sonucuna varmışlardır.

Alan yazında ayrıca matematik öğretmeni ve adaylarının, öğretmen kavramına yönelik algılarının metaforlar aracılığıyla incelendiği çalışmalara da (Oksanen, Portaankorva-Koivisto ve Hannula, 2014; Yılmaz, Göçen ve Yılmaz, 2013) rastlanmıştır. Örneğin Oksanen vd. (2014) öğretmen adayları tarafından en sık kendine referans eden metaforunu, öğretmenler tarafından ise didaktik metaforunun üretildiğini ortaya koymuşlardır. Üretilen metaforların ise beş farklı kategoride yer aldığını belirtmişlerdir. Yılmaz vd. (2013) ise adayların öğretmen kavramını anne-baba, aile, rehber, bahçıvan, ışık ve çoban gibi metaforlar ile açıklandığını ve bu metaforların ise şekillendirici, bilgi kaynağı, yol gösterici, esnek, statüsüz, model ve kutsal bir iş yapan öğretmen kavramsal kategorileri altında toplandığı sonucuna ulaşmışlardır.

Noyes (2006) ise çalışmasında matematik öğretmeni adaylarının, matematik ve matematik öğrenme-öğretme ile ilgili inançlarını metaforlar aracılığıyla incelemiştir. Ayrıca matematiğin; yapı, seyahat, araç takımı ve dil olmak üzere dört ana metafor ile ifade edildiğini ortaya çıkarmıştır. Çırak-Kurt ve Yıldırım (2020) matematik öğretmeni adayları ve mesleğe yeni başlamış öğretmenler ile yaptıkları çalışmalarında, katılımcıların öğrenci, matematik öğretim programı, matematik öğretmek ve öğretmenlik kavramlarına yönelik algılarını, metaforlar aracılığıyla ortaya koymayı amaçlamışlardır. Bu bağlamda öğretmen adayları tarafından matematik öğretmek ile ilgili üretilen metaforların; kılavuzluk, verimliliği sağlama, düşünmeyi öğretme, merak uyandırma, ustalık isteyen bir süreç, anlamlandırmayı sağlama ve birikimli süreç kategorileri altında toplandığı sonucu elde edilmiştir.

Şahin (2013) yaptığı araştırmada, matematik ve matematik öğretmeni kavramlarını bir arada ele almasına karşın, çalışmasını ne ortaokul ne de lise matematik öğretmeni adayları ile gerçekleştirmemiştir. Çalışmaya fen ve teknoloji, sınıf, okul öncesi, Almanca, İngilizce, Türkçe, resim ve sosyal bilgiler öğretmeni olacak adaylar katılımışlardır. Bu çalışmada, matematik kavramının zekâ, zevkli, gerekli, yetenek, zor ve başarı metaforlarıyla ilişkilendirildiğini; matematik öğretmeni kavramının ise bilgili ve otoriter metaforlarıyla ilişkilendirildiğini belirlemiştir. Her iki kavramın bir arada ele alındığı diğer bir araştırma ise pedagojik formasyon sertifika programına katılan öğretmen adayları ile yürütülmüştür. Bu çalışmanın katılımıılarının matematik ve matematik öğretmeni kavramlarına yönelik daha çok olumsuz metaforlar ürettikleri sonucuna erişilmiştir (Taşpınar-Şener, Ünal ve Aydın, 2016).

Oysa matematik dersi ilk defa ortaokul düzeyinde bağımsız bir ders olarak tek bir öğretmen tarafından öğretilmeye başlanmaktadır. Bu sebeple de ilk defa bağımsız bir ders olarak öğretimini yapacak olan ortaokul matematik öğretmeni adaylarının hem matematik hem de matematik öğretmeni kavramlarına yönelik algılarının incelenmesinin alan araştırmalarına 1şık tutacağı ön görülmektedir. Nitekim Demirkol ve Ergin (2017) çalışmalarında her iki kavrama yönelik algıları hem ortaokul matematik öğretmeni adayları hem de pedagojik formasyon sertifika programına katılan öğretmen adayları bağlamında incelemişlerdir. Gerçekleştirilen araştırma, literatürdeki bu çalışma ile paralellik göstermesine karşın, farklı bir grup ile çalışılmış olması sebebiyle matematik ve matematik öğretmenine yönelik ortaokul matematik öğretmeni adaylarının algılarını karşılaştırmaya olanak sağlayacaktır. Ayrıca ülkemizin farklı üniversitelerinde öğrenim görmekte olan ortaokul matematik öğretmeni adaylarının bu kavramlara yönelik algılarının ne şekilde değişip değişmediği de görülebilecektir. Bu açıdan da araştırmanın ilgili literatüre katkı sağlayacağı düşünülmektedir. Bu sebeple bu araştırmanın amacı, ortaokul matematik öğretmeni adaylarının matematik ve matematik öğretmeni kavramlarına ilişkin 
algılarının metaforlar aracılığıyla incelenmesidir. Bu çerçevede araştırmanın amacına ulaşabilmek için aşağıdaki araştırma problemlerinin cevapları aranmıştır.

1. OMÖA'nın matematik kavramı ile ilgili oluşturdukları metaforlar nelerdir?

2. OMÖA'nın matematik kavramı ile ilgili oluşturdukları metaforlar, hangi kavramsal kategoriler altında toplanmaktadır?

3. OMÖA'nın matematik öğretmeni kavramı ile ilgili oluşturdukları metaforlar nelerdir?

4. OMÖA'nın matematik öğretmeni kavramı ile ilgili oluşturdukları metaforlar, hangi kavramsal kategoriler altında toplanmaktadır?

\section{YÖNTEM}

\subsection{Araștırma Modeli}

Araştırma, olgubilim desenine göre tasarlanmıştır. Olgubilim çalışmaları, farkında olduğumuz ancak ayrıntılı ve derinlemesine bir anlayışa sahip olmadığımız olgulara odaklanmaktadır (Cropley, 2002). Umay (2002), matematiği zor bulanlardan tanımını yapmaları istendiğinde ne yapacaklarını merak etmiş ve matematiği tanımlanması zor kavramlardan biri olarak belirtmiştir. Bunu da matematiğin toplumda yaygın olarak tanınmaması ile ilişkilendirmiştir. Dolayısıyla matematik ve matematik öğretmeni kavramlarına yönelik bir algılayışa sahip olmamıza rağmen bu kavramlarla ilgili olarak ayrıntılı ve derinlemesine bir anlayışa sahip olmadığımız düşünülmektedir. Bu da göz önüne alındığında, matematik ve matematik öğretmeni kavramları, anlaşılması gereken iki olgu olarak karşımıza çıkmaktadır. Ayrıca olgubilimde, bir grup bireyin deneyimlediği bir olgunun anlamının, özünün ve yapısının anlaşılması ve açıklanması hedeflenmektedir (Patton, 2002). Buna ek olarak belirlenen olgu anahtar bir fikir, kavram ya da sürecin kendisi olabilmektedir (Creswell, 2007). Bu araştırmanın anahtarları ise "matematik" ve "matematik öğretmeni" kavramlarına yönelik öğretmen adaylarının algılarıdır. Bu sebeple de olgubilim, bu araştırmanın modeli olarak uygun görülmüştür.

\subsection{Calıșma Grubu}

Araştırmanın çalışma grubu, uygun örneklemeye göre belirlenmiştir. Bu örneklemede amaç, zaman ve işgücü kaybını önlemektir. Araştırmacı maksimum tasarrufu sağlamak adına en ulaşılabilir yanıtlayıcılardan başlamak üzere örneklemini oluşturur (Cohen ve Manion, 1989; Ravid, 1994). Bu araştırmaya katılan öğretmen adayları da araştırmacılardan birinin görev yapmakta olduğu eğitim fakültesinde öğrenim görmekte olan ve gönüllü katılım sağlayan öğrencilerdir. Bu sebeple de katılımcılar, araştırmacılar için en ulaşılabilir yanıtlayıcılar olup zaman ve işgücü kaybını en aza indirgemişlerdir. Bu kapsamda araştırmaya, ilköğretim matematik öğretmenliği programı dördüncü sınıfta öğrenim görmekte olan 59 öğretmen adayı katılmıştır. Araştırmaya katılan 59 öğretmen adayının 12'si erkek 47'si kadındır.

\subsection{Veri Toplama Aracı}

$\mathrm{Bu}$ araştırma için veriler, araştırmacılar tarafından hazırlanan "Matematik ve Matematik Öğretmeni Metaforları Anketi (MMÖMA)" ile elde edilmiştir. Anket üç bölümden meydana gelmektedir. Birinci bölümde, araştırmaya katılacak bireylerin cinsiyet ve öğrenim gördükleri sınıf düzeyi bilgilerine erişebilmek için sorular bulunmaktadır. İkinci bölümde "Matematik ............... gibidir; çünkü ." cümlesi yer almaktadır. Üçüncü bölümde ise "Matematik ögretmeni gibidir; çünkü ..................” ifadesine yer verilmiştir.

Araştırmaya katılanlardan ikinci ve üçüncü bölümde verilen ifadelerdeki ilk boşluğa matematiği ve matematik öğretmenini ifade eden bir metafor yazmaları, ikinci boşluğa da niçin bu metaforu yazdıklarını açıklayan cümlelerini yazmaları istenmiştir. Bu noktada öğretmen adayları tarafından aynı metaforlar üretilebilir. Bunun nedenini Yıldırım ve Şimşek (2008), her bireyin aynı metafora farklı anlamlar yüklemesi olarak açıklamaktadır. Dolayısıyla üretilen metaforun ne amaçla yazıldığı ancak niçin sorusuna verilen yanıtlardan elde edilebilmektedir. Bu sebeple bu araştırmada, üretilen metaforların neden üretildiğini anlayabilmek adına çünkü ifadesinden sonra metaforun üretilme nedeninin yazılması istenmiştir. Katılımcılar tarafından doldurulan bu anketler, birer doküman olarak araştırmacıların temel veri kaynaklarını oluşturmuşlardır. Anketin doldurulması, katılımcıların düşünme hızı, yaratıcılık, üretilen metafora yüklenen anlamın açıklanmasına yönelik anlamsal bilgi vb. gibi değişkenlere göre 
değişebilecek olsa da bu araştırmada, katılımcılara anketi doldurmaları için 20 dakika süre verilmiştir. Gelecek araştırmalarda bu süre katılımcılara ve kullanılacak olan veri toplama araçlarına göre ayarlanabilir.

\subsection{Verilerin Analizi}

İlk olarak toplanan anketler detaylı bir şekilde incelenmiștir. Bu incelemede, herhangi bir boş anketin olmadığı tespit edilmiştir. Bu bağlamda anketler sıralanarak Ortaokul Matematik Öğretmeni Adayı = OMÖA olacak şekilde; OMÖA1, OMÖA2, ..., OMÖA59 olarak kodlanmıştır. Bu kodlamanın ardından veriler içerik analizine tabi tutulmuştur. $\mathrm{Bu}$ analizde elde edilen verileri açıklamak üzere kavram ve ilişkileri elde etmek temel amaçtır. Bu temel amaçla yapılan işlemde, birbirine benzer verilerin, belirli kavram ve temalar altında bir araya getirilerek bunların, okuyucuların anlayacağı şekilde organize edilmesi ve yorumlanması yer almaktadır (Yıldırım ve Şimşek, 2008). Bu süreçte ise; i) adlandırma, ii) eleme, iii) kategori ve iv) geçerlik-güvenirlik sağlama aşamaları takip edilmiştir (Saban, 2009). Bu aşamalarda gerçekleştirilen işlemler aşağıda detaylı bir şekilde açıklanmıştır.

Adlandırma aşaması: Analizin bu aşamasında elde edilen tüm verilerin, geçerli-geçersiz olup olmadıklarına bakılmaksızın listelenmesi söz konusudur. Bu bağlamda elde edilen tüm metaforlar listelenmiş ve matematik için toplamda 60; matematik öğretmeni için ise toplamda 59 metaforun üretildiği belirlenmiştir. Katılımcı sayısı 59 olmasına rağmen matematik için 60 metaforun olma sebebi, bir öğretmen adayının iki metafor ve açıklama oluşturmasıdır.

Eleme aşaması: $\mathrm{Bu}$ aşamada geçersiz metaforlar ile metaforu geçerli olup açıklaması geçersiz olan verilerin elenmesi gerekmektedir. Örneğin; "Matematik bulmaca gibidir; çünkü düşünmeyi gerektirir, düşünürken aynı zamanda eğlenmeyi sağlar, içerisinde sonsuz bilgi barındırır" ifadesinde matematik "bulmaca" metaforu ile ilişkilendirilmiş olup bu metafor geçerlidir. Metaforun gerekçesine bakıldığı zaman bulmacalar düşünmeyi gerektirirken eğlenmeyi de sağlamaktadır şeklindedir. Bulmaca, çeşitli şekillerde düzenlenen ve düşündürerek buldurmayı amaç edinen oyun (TDK, 2021c) olarak tanımlanmaktadır. $\mathrm{Bu}$ tanım bağlamında üretilen metaforun açıklaması da geçerli olarak değerlendirilmiştir. Diğer bir örnek ise; "Matematik öğretmeni, güneş gibidir; çünkü etrafindakileri aydınlatır" ifadesinde matematik öğretmeni "güneş" metaforu ile ilişkilendirilmiş olup bu metaforun açıklaması etrafındakileri aydınlatmasıdır. Güneş, yer yuvarlağına ve gezegenlere ışık veren büyük gök cismi (TDK, 2021d) olarak ifade edilmekte iken ışık, bir yeri aydınlatmaya yarayan araç (TDK, 2021e) olarak belirtilmektedir. $\mathrm{Bu}$ tanımlar kapsamında üretilen metaforun açıklaması da geçerli olarak görülmüştür. Örneklerde sunulduğu şekilde hem matematiğe hem de matematik öğretmenine yönelik üretilen metaforlar tek tek incelenmiş ve hem metafor hem de gerekçe bağlamlarında geçerli olup olmadıklarına bakılmıştır. Yapılan inceleme sonucunda üretilen tüm metaforlar ile gerekçelerinin geçerli olduğu kanaatine varılmıştır. Sonuçta elenen herhangi bir metafor olmadığı için üretilen metaforlarla diğer aşamalara geçiş yapılmıştır.

Kategori aşaması: $\mathrm{Bu}$ aşamada hem matematik hem de matematik öğretmeni kavramlarına ilişkin ortaya konan metaforların, ortak özellikler bakımından irdelenmesi ve kavramsal kategoriler altında toplanması gerekmektedir. Kavramsal kategoriler oluşturulurken dikkat edilen nokta, oluşturulan metafor ve metaforun kaynağından konusuna atfedilen düşüncenin hangi kategori altında yer alması gerektiğidir. Örneğin; "Matematik, hesap makinesi gibidir; çünkü her türlü problemi çözmemize yardımcı olur" biçiminde yazılan bir cümlede metaforun kaynağı "hesap makinesi" iken konusuna kaynaktan atfedilen düşünce "her türlü problemin çözülmesine yardımcı olması"dır. Bu ifadeden matematiğin her türlü problemin çözülmesine yardımcı olduğu düşünülmektedir. Bu örnekteki şekilde, iki araştırmacı ayrı ayrı, hem matematik hem de matematik öğretmenine yönelik üretilen metaforları incelemişlerdir. Her bir araştırmacı metaforları kendi belirledikleri kavramsal kategoriler altında toplamışlardır. Daha sonra bir araya gelerek metaforların hangi kavramsal kategoriler altında yer alması gerektiğine karar vermişlerdir. Anlaşma sağlanamayan kategoriler ile ilgili olarak üçüncü bir araştırmacıdan destek alınmıştır. Yapılan 
kategorilendirmeler üçüncü araştırmacıya gerekçeleri ile açıklanmış ve araştırmacıdan en makul kategoriyi belirlemesi istenmiştir. Belirlenen kategoriler bulgular bölümünde sunulmuştur.

Geçerlik-güvenirlik sağlama aşaması: Bu aşamanın sağlanabilmesi için, diğer tüm aşamaların ayrı ayrı araştırmacılar tarafından ele alınması gerekmektedir. Bu sebeple de tüm araştırmacılar tarafından elde edilen veriler ayrı ayrı analiz edilmiştir. Lincoln ve Guba (1985; akt. Yıldırım ve Şimşek, 2008) nitel araştırmalar için iç geçerlik yerine inandırıcılık; dış geçerlik için de aktarılabilirlik kavramlarının kullanılmasını önermektedirler. Yapılan araştırmanın uzman kişilerce çeşitli boyutlarıyla detaylı bir şekilde incelenmesinin istenmesi inandırıcılık konusunda yapılan işlemlerden biridir. Uzman incelemesi araştırmacı ile birlikte değerlendirme toplantısı şeklinde gerçekleştirilebilir (Yıldırım ve Şimşek, 2008). İnandırıcıllğın sağlanması amacıyla araştırmacılardan farklı bir araştırmacıya çalışmayı değerlendirmesi istenmiş ve yapmış olduğu değerlendirmeyi paylaşması için bir değerlendirme toplantısı yapılmıştır. Aktarılabilirlik, verilerin yeterli düzeyde betimlenmesine bağlıdır. $\mathrm{Bu}$ sebeple de doğrudan alıntılara araştırma içinde sık sık yer verilmektedir (Yıldırım ve Şimşek, 2008). Çalışmanın bulgular bölümünde görüleceği üzere metafor ve açıklamalarına ilişkin sık sık doğrudan alıntılara yer verilmiştir. Bu bağlamda çalışmanın geçerliği sağlanmıştır. Daha sonra elde edilen sonuçlara yönelik güvenirlik, Miles ve Hubermann (1994) tarafindan sunulan (Güvenirlik=görüş birliği/görüş birliği + görüş ayrıllğı x 100) formülü ile hesaplanmıştır. Sonuçta, matematiğe yönelik metafor ve gerekçeleri ile ilgili verilerin güvenirliği için araştırmacılar arası uzlaşma oranı $\% 92$, matematik öğretmenine yönelik metafor ve gerekçeleri ile ilgili verilerin güvenirliği için uzlaşma oranı ise $\% 86$ şeklinde elde edilmiştir.

Birinci ve üçüncü araştırma problemlerine ilişkin bulgular sunulurken hem metafor bulutlarından hem de tablolardan yararlanılmıştır. Metafor bulutlarının oluşturulmasındaki amaç, öne çıkan kavramların daha görsel bir şekilde sunulması ve dikkat çekiciliği artırmasıdır. Metafor bulutlarının yanı sıra tabloların verilme gerekçesi ise her bir metaforun kaç katılımcı tarafından üretildiğinin görülebilmesini sağlamaktır. Bulutların hazırlanmasında Word Art Creator uygulaması kullanılmıştır.

\subsection{Etik Kurul Onay Bilgisi}

Bu çalışmada 2020 yılı ve öncesi verileri kullanılmış olup, çalışma süresince etik ilkelere dikkat edilmiştir. $\mathrm{Bu}$ ilkeler çerçevesinde katılımcı gönüllülüğü esas alınarak onları tanıtıcı bilgiler gizli tutulmuş ve veriler sadece bu bilimsel araştırmada kullanılmıştır.

2. BULGULAR

2.1. Birinci Alt Problem ile İlgili Bulgular

$\mathrm{Bu}$ araştırmanın ilk alt problemi, "OMÖA'nın matematik kavramı ile ilgili oluşturdukları metaforlar nelerdir?" ş̧eklinde belirlenmiştir. Öğretmen adayları matematik kavramı ile ilgili olarak 60 metafor üretmişlerdir. Bu metaforlar aşağıda Şekil 1'de sunulan matematik metafor bulutundaki gibidir. 


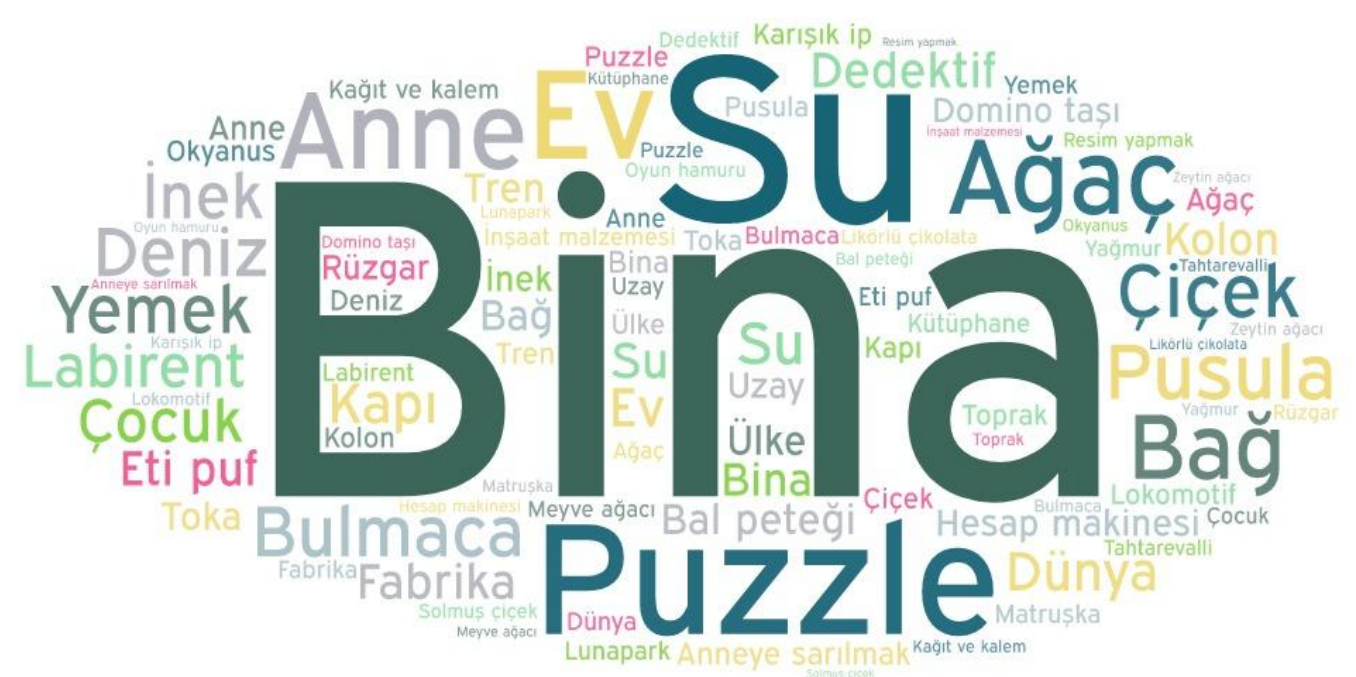

Şekil 1: OMÖA'nın Matematik İle İlgili Ürettikleri Metaforlar

Şekil 1'de sunulan matematik metafor bulutuna göre, öğretmen adayları tarafından öne çıkarılan metaforlar; bina, puzzle ve su metaforlarıdır. Şekil 1'de sunulmuş olan tüm bu metaforlara ilişkin bulgular, frekans bazında aşağıda Tablo 1'de sunulduğu şekildedir.

Tablo 1: OMÖA'nın Matematik Kavramı ile İlgili Ürettiği Tüm Metaforlar

\begin{tabular}{clccll}
\hline Sıra No (SN) & \multicolumn{1}{c}{ Metafor } & Frekans (f) & SN & \multicolumn{1}{c}{ Metafor } & f \\
\hline 1 & Bina & 3 & 25 & Kağıt ve Kalem & 1 \\
2 & Puzzle & 3 & 26 & Kapı & 1 \\
3 & Su & 3 & 27 & Karışı İp & 1 \\
4 & Ağaç & 2 & 28 & Kolon & 1 \\
5 & Anne & 2 & 29 & Kütüphane & 1 \\
6 & Bulmaca & 2 & 30 & Likörlü Çikolata & 1 \\
7 & Hesap Makinesi & 2 & 31 & Lokomotif & 1 \\
8 & Labirent & 2 & 32 & Lunapark & 1 \\
9 & Pusula & 2 & 33 & Matruşka & 1 \\
10 & Yemek & 2 & 34 & Meyve Ağacı & 1 \\
11 & Anneye Sarılmak & 1 & 35 & Okyanus & 1 \\
12 & Bă̆ & 1 & 36 & Oyun Hamuru & 1 \\
13 & Bal Peteği & 1 & 37 & Resim Yapmak & 1 \\
14 & Çiçek & 1 & 38 & Rüzgâr & 1 \\
15 & Çocuk & 1 & 39 & Solmuş Çiçek & 1 \\
16 & Dedektif & 1 & 40 & Tahterevalli & 1 \\
17 & Deniz & 1 & 41 & Toka & 1 \\
18 & Domino Taş1 & 1 & 42 & Toprak & 1 \\
19 & Dünya & 1 & 43 & Tren & 1 \\
20 & Eti Puf & 1 & 44 & Uzay & 1 \\
21 & Ev & 1 & 45 & Ülke & 1 \\
22 & Fabrika & 1 & 46 & Yağmur & 1 \\
23 & İnek & 1 & 47 & Zeytin Ağacı & 1 \\
24 & İnşaat Malzemesi & 1 & & & \\
\hline Toplam (T) & & & & & $\mathbf{6 0}$ \\
\hline & & & & &
\end{tabular}


Tablo 1'e göre, ortaokul matematik öğretmeni adaylarının, matematik kavramı ile ilgili olarak 47 farklı metafor oluşturdukları görülmüştür. Şekil 1'de de görüldüğü üzere öğretmen adayları tarafından en çok tekrarlanan metaforlar; bina, puzzle ve su olarak belirlenmiştir. Bu metaforlar üçer öğretmen adayı tarafından oluşturulmuş olup metafor ve gerekçeleri ile ilgili örnekler aşağıdaki gibidir.

"Matematik, bina gibidir; çünkü bir binanın içinde birbirinden farklı kafalar, insanlar vardır. Hepsinin içerisinde bilgi bulunmaktadır. Bu kafalar bir araya gelerek bu binayı inşa etmektedirler. Matematik de bir şeyleri inşa etmek gibidir.” (OMÖA28)

"Matematik, puzzle gibidir; çünkü evrene dair her alanla ilgili bir parçaya sahiptir ve onsuz puzzle tamamlanmaz." (OMÖA23)

"Matematik, su gibidir; çünkü nasıl ki suya ihtiyacımız var matematiğe de ihtiyacımız var. O olmadan hayat olmaz." (OMÖA37)

Yukarıda sunulan metaforları, ikişer öğretmen adayının belirttiği; ağaç, anne, bulmaca, hesap makinesi, labirent, pusula ve yemek metaforları takip etmektedir. Kalan 37 metafor ise birer öğretmen adayı tarafından ifade edilmiştir. Bu metaforlardan bazıları; bă̆, bal peteği, lokomotif, okyanus vb. şeklindedir. Bu metaforlar ve gerçekleri ile ilgili örnekler aşağıda sunulmuştur.

"Matematik, ăgaç gibidir; çünkü çok sağlamdır. Fazlaca dalı vardır. Çok fazla bilgi barındırır." (OMÖA17)

"Matematik, anne gibidir; çünkü karşılaştığımız bütün sorunlarda çözüm yolu bulmamıza yardımcı olur, analitik düşünmemizi sağlar.” (OMÖA22)

"Matematik, bulmaca gibidir; çünkü düşünmeyi gerektirir. Düşünürken aynı zamanda ĕglenmeyi săglar. İçerisinde sonsuz bilgi barındırır.” (OMÖA58)

"Matematik, hesap makinesi gibidir; çünkü içinde bir sürü bilgi barındırır ve bu bilgiler gerektiğinde kullanılır.” (OMÖA36)

"Matematik, labirent gibidir; çünkü birden fazla gidiş yolu olmasına ră̆men çıkış noktası tektir. Çıkış noktasına gidebilmek için zaman ve emek gerekir.” (OMÖA53)

“Matematik, pusula gibidir; çünkü yön bulmayı sağlar.” (OMÖA34)

"Matematik, yemek gibidir; çünkü bir sürü içeriğin bir araya gelmesi ile çok lezzetli sonuç çıkar.” (OMÖA44)

“Matematik, anneye sarllmak gibidir; çünkü bütün sorunlara çözümdür.” (OMÖA42)

\section{2. İkinci Alt Problem ile İlgili Bulgular}

İkinci araştırma problemi, "OMÖA'nın matematik kavramı ile ilgili oluşturdukları metaforlar, hangi kavramsal kategoriler altında toplanmaktadır?” şeklinde ele alınmıştır. Buradaki amaç, öğretmen adaylarının matematiği ne şekilde gördüklerinin daha detaylı olarak ortaya konmasını sağlamaktır. Bu kapsamda yapılan değerlendirme sonucunda, matematik kavramına ilişkin üretilen metaforların altı tane kavramsal kategori altında toplandığı bulgusu elde edilmiştir. Bu kavramsal kategoriler; içerik/yap1 ( $f=29$ ), duruma görelik ( $f=9$ ), sonsuzluk ( $f=7$ ), yol gösterici/rehber ( $f=7)$, zevk/eğlence ( $f=7$ ) ve her şeyde/yerde ( $\mathrm{f}=4)$ şeklindedir. Bu kavramsal kategoriler ile ilgili bulgular aşağıda sunulduğu şekildedir. 
1. İ̧̧erik/Yapı

Araştırmaya katılan öğretmen adaylarının matematiğin içeriğine ve/veya yapısına atıfta bulunan 25 farklı, toplam 29 metafor ürettikleri görülmüştür. Elde edilen bulgular aşağıda Tablo 2'de görülebilmektedir.

Tablo 2: İçerik/Yap1

\begin{tabular}{lllllllll}
\hline SN & Metafor & f & SN & \multicolumn{1}{c}{ Metafor } & f & SN & \multicolumn{1}{c}{ Metafor } & f \\
\hline 1 & Bina & 3 & 10 & Lokomotif & 1 & 19 & İşaat Malzemesi & 1 \\
2 & Ağaç & 2 & 11 & Tren & 1 & 20 & Eti Puf & 1 \\
3 & Labirent & 2 & 12 & Puzzle & 1 & 21 & Yemek & 1 \\
4 & Bağ & 1 & 13 & Zeytin Ağacı & 1 & 22 & Resim Yapmak & 1 \\
5 & Dünya & 1 & 14 & Okyanus & 1 & 23 & Ülke & 1 \\
6 & Kütüphane & 1 & 15 & Bal Peteği & 1 & 24 & Fabrika & 1 \\
7 & Kolon & 1 & 16 & Domino Taşları & 1 & 25 & Bulmaca & 1 \\
8 & Matruska & 1 & 17 & Hesap Makinesi & 1 & & & \\
9 & Dedektif & 1 & 18 & Meyve Ağac1 & 1 & & & \\
\hline T & & & & & & \\
\hline
\end{tabular}

Tablo 2'ye bakıldığında, bu metaforlardan bina, üç öğretmen adayı tarafından, ağaç ve labirent ikişer öğretmen adayı tarafından yazılırken diğer metaforlar birer öğretmen adayı tarafindan oluşturulmuştur. Tüm bu metaforlar incelendiğinde, matematiğin birbiriyle bağlantılı farklı konuları içeren, çeşitli çözüm yollarının yanında tek bir sonuca sahip, temeli sağlam atılması gereken ve düşünme gerektiren aşamalı bir döngü olarak ifade edildiği belirlenmiştir. Örneğin;

"Matematik, bina gibidir; çünkü temeli sağlam olmazsa sürekli seni sarsar." (OMÖA59)

"Matematik, ăgaç gibidir; çünkü çok sağlamdır, fazlaca dalı vardır, çok fazla bilgi barındırır." (OMÖA16)

"Matematik, labirent gibidir; çünkü birden fazla gidiş yolu olmasına rağmen çıkış noktast tektir.” (OMÖA51)

"Matematik, dünya gibidir; çünkü her branşı içinde barındıran sonsuz bir döngü içerisindedir. Dünya gibi her şey, her şeyle bağlantıll ve uyumludur.” (OMÖA6)

2. Duruma Görelik

Öğretmen adaylarının “duruma görelik” kavramsal kategorisi ile ilgili olarak dokuz farklı metafor ürettikleri belirlenmiştir. Tüm metaforlar birer öğretmen adayı tarafından oluşturulmuştur. Bu metaforlar; oyun hamuru, rüzgâr, toka, tahterevalli, çocuk, yemek, likörlü çikolata, solmuş çiçek ve inek şeklindedir. Kaynaklarından atfedilen düşünceler göz önüne alındığında, matematiğin duruma göre değişen yapısına odaklandıkları görülmüştür. Örneğin;

"Matematik, rüzgâr gibidir; çünkü bazen bir ılık rüzgâr gibi hoşuna gider bazen de başını ăgrıtır." (OMAÖ15)

“Matematik, likörlü çikolata gibidir; çünkü tadını almasını bilene hoş gelir, bilmeyenin boğazını yakar, keyfini kaçırır.” (OMAÖ54)

3. Sonsuzluk

"Sonsuzluk" kavramsal kategorisi ile ilgili yedi farklı metaforun oluşturulduğu belirlenmiştir. Bu metaforlar; toprak, uzay, su, yağmur, kapı, bulmaca ve deniz şeklinde olup birer öğretmen adayı tarafından yazılmışlardır. Tüm metaforlar ve kaynaklarından konusuna atfedilen düşünceler 
incelendiğinde, ortaokul matematik öğretmeni adaylarının, matematiğin ucu bucağı olmayan ve sonsuz bilgi içeren boyutuna odaklandıkları belirlenmiştir. Örneğin;

“Matematik, bulmaca gibidir; çünkü içerisinde sonsuz bilgi barındırır.” (OMAÖ56)

“Matematik, deniz gibidir; çünkü ucu bucă̆ı olmayan sonsuzluktadır.” (OMAÖ57)

4. Yol Gösterici/Rehber

Araştırmaya katılan öğretmen adaylarının "yol gösterici/rehber” kavramsal kategorisi ile ilgili beş farklı, toplam yedi metafor yazdıkları belirlenmiştir. Bu metaforlardan pusula ve anne ikişer öğretmen adayı tarafından oluşturulurken hesap makinesi, anneye sarılmak ve su metaforları birer öğretmen adayı tarafından oluşturulmuştur. Tüm metaforların kaynakları incelendiğinde, matematiğin karşılaşılan her türlü sorunda çözüm yolunu bulmamızı sağlayan rehber boyutuna değinildiği bulgusuna ulaşılmıştır. Örneğin;

“Matematik, pusula gibidir; çünkü herkese yol gösterir.” (OMAÖ5)

"Matematik, anne gibidir; çünkü karşılaştı̆̆ımız bütün sorunlarda çözüm yolu bulmamıza yardımcı olur.” (OMAÖ21)

5. Zevk/Ĕ̈lence

Öğretmen adayları "zevk/eğlence” kavramsal kategorisi ile ilgili beş farklı, toplam yedi metafor üretmişlerdir. Bulmaca ve yapboz metaforları ikişer öğretmen adayı tarafından yazılırken lunapark, çiçek ve karışık ip metaforları birer öğretmen adayı tarafından yazılmıştır. Tüm metaforların kaynaklarından atfedilen düşüncelere göz atıldığında, matematiğin her konusu ayrı zevkli olan ve düşünürken eğlenmeyi sağlayan boyutuna odaklandıkları belirlenmiştir. Örneğin;

“Matematik, lunapark gibidir; çünkü her konusu ayrı bir zevklidir.” (OMAÖ4)

"Matematik, bulmaca gibidir; çünkü düşünürken aynı zamanda eğlenmeyi sağlar." (OMÖA56)

6. Her Şeyde/Yerde

Katılımcıların "her şeyde/yerde" kavramsal kategorisi ile ilgili olarak dört farklı metafor yazdıkları belirlenmiştir. Bu metaforlar; ev, su, yapboz ile kâğıt ve kalem şeklinde olup birer öğretmen adayı tarafından yazılmışlardır. Metaforların kaynaklarından konularına atfedilen düşünceler incelendiğinde, matematiğin hayatın her yerinde ve her şekilde kullanıldığına odaklanıldığı belirlenmiştir. Örneğin;

"Matematik, yapboz gibidir; çünkü hayatınızda matematiği her yerde ve her şekilde kullanabilirsiniz.” (OMÖA28)

“Matematik, ev gibidir; çünkü hayatın her alanında vardır.” (OMAÖ34)

\section{3. Üçüncü Alt Problem ile İlgili Bulgular}

Üçüncü araştırma problemi, “OMÖA'nın matematik ögretmeni kavramı ile ilgili oluşturdukları metaforlar nelerdir?” olarak belirlenmiştir. Öğretmen adaylarının matematik öğretmeni kavramına yönelik 59 metafor oluşturdukları görülmüştür. Bu metaforlar ilk olarak aşağıda Şekil 2'deki matematik ögretmeni metafor bulutunda sunulmuştur. 


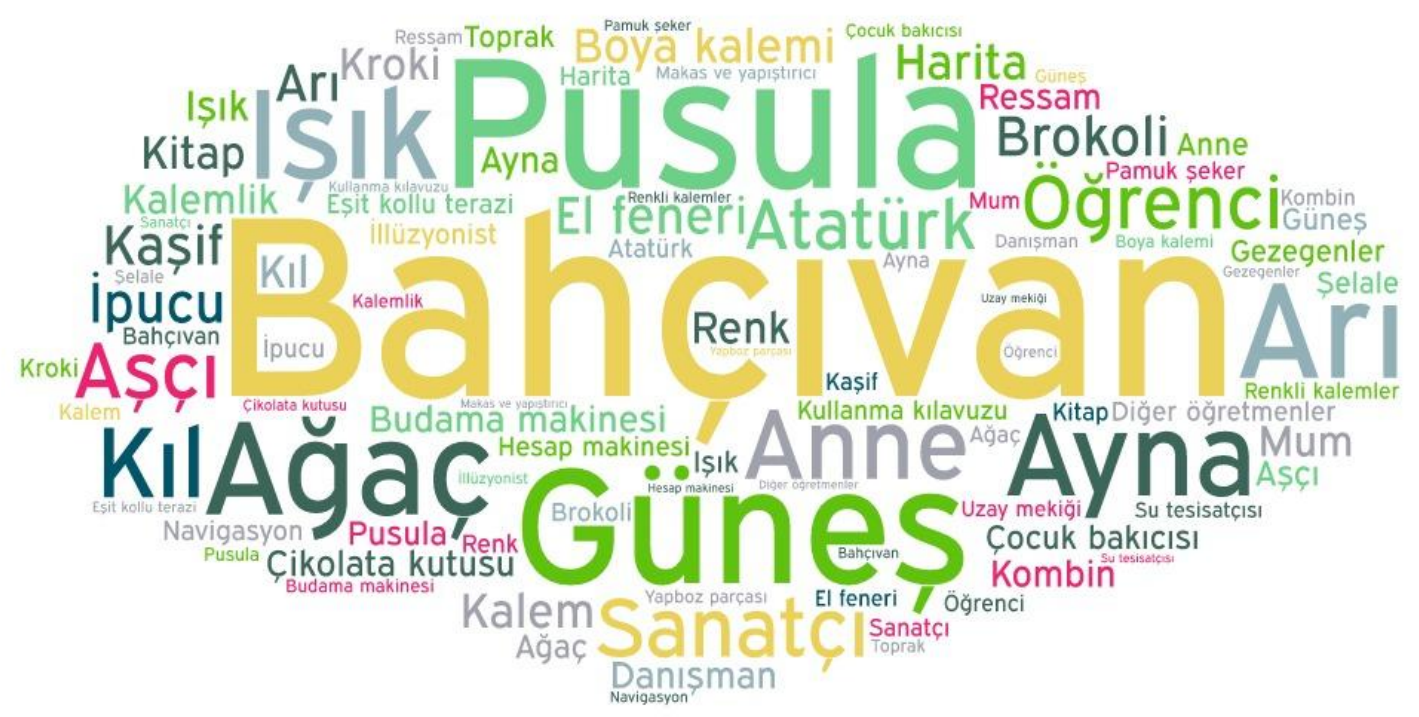

Şekil 2: OMÖA’nın Matematik Öğretmeni İle İlgili Ürettikleri Metaforlar

Şekil 2'de sunulan matematik öğretmeni metafor bulutuna göre, öğretmen adayları tarafindan öne çıkarılan metaforlar; bahçıvan, pusula ve güneş metaforlarıdır. Şekil 2'de sunulmuş olan tüm bu metaforlara ilişkin bulgular, frekans bazında Tablo 3 'te aşağıda sunulduğu şekildedir.

Tablo 3: OMÖA'nın Matematik Öğretmeni Kavramı ile İlgili Ürettiği Tüm Metaforlar

\begin{tabular}{llllll}
\hline \multicolumn{1}{c}{ SN } & \multicolumn{1}{c}{ Metafor } & f & SN & \multicolumn{1}{c}{ Metafor } & f \\
\hline 1 & Bahçıan & 4 & 24 & Hesap makinesi & 1 \\
2 & Pusula & 4 & 25 & İllüzyonist & 1 \\
3 & Güneş & 3 & 26 & İpucu & 1 \\
4 & Ağaç & 2 & 27 & Kalem & 1 \\
5 & Ayna & 2 & 28 & Kalemlik & 1 \\
6 & Işık & 2 & 29 & Kâşif & 1 \\
7 & Ögrenci & 2 & 30 & Kıl & 1 \\
8 & Sanatçı & 2 & 31 & Kitap & 1 \\
9 & Anne & 1 & 32 & Kombin & 1 \\
10 & Arı & 1 & 33 & Kroki & 1 \\
11 & Aşçı & 1 & 34 & Kullanma kılavuzu & 1 \\
12 & Atatürk olmak & 1 & 35 & Makas ve yapıştırıcı & 1 \\
13 & Boya kalemi & 1 & 36 & Mum & 1 \\
14 & Brokoli & 1 & 37 & Navigasyon & 1 \\
15 & Budama makinesi & 1 & 38 & Pamuk şeker & 1 \\
16 & Çikolata kutusu & 1 & 39 & Renk & 1 \\
17 & Çocuk bakıcısı & 1 & 40 & Renkli kalemler & 1 \\
18 & Danışman & 1 & 41 & Ressam & 1 \\
19 & Diğer öğretmenler & 1 & 42 & Su tesisatçısı & 1 \\
20 & El feneri & 1 & 43 & Şelale & 1 \\
21 & Eşit kollu terazi & 1 & 44 & Toprak & 1 \\
22 & Gezegenler & 1 & 45 & Uzay mekiği & 1 \\
23 & Harita & 1 & 46 & Yapboz parçası & 1 \\
\hline Toplam & & & & $\mathbf{5 9}$ \\
\hline
\end{tabular}

Tablo 3 incelendiğinde, ortaokul matematik öğretmeni adaylarının matematik öğretmeni ile ilgili 46 farklı metafor ürettikleri görülmektedir. Bu metaforlardan bahçıvan ve pusula metaforları dörder 
öğretmen adayı tarafından tercih edilmiştir. Bu metaforlar ve gerekçeleri ile ilgili örnekler aşağıdaki şekildedir.

"Matematik öğretmeni bahçıvan gibidir; çünkü bir sürü ögrenciyi bir çiçek gibi yetiştirir.” (OMÖA24)

"Matematik ögrretmeni bahçıvan gibidir; çünkü bahçesindeki bitkilerine gözü gibi bakar. Güneşi iyi alabileceği bir yere koyar. Bitkilerine suyunu verir, yeri geldiğinde de bitkinin iyiliği için budar. Tipkı matematik ögretmeninin, öğrencilerine olan ögretme çabası gibi." (OMÖA39)

“Matematik öğretmeni pusula gibidir; çünkü yön, yol gösterir. Öğrencinin bilgiye ulaşması için rehber olur." (OMÖA56)

“Matematik öğretmeni pusula gibidir; çünkü öğrencilerine doğru yolu gösterir." (OMÖA59)

Yukarıdaki metaforları üç öğretmen adayının ürettiği güneş metaforu takip etmektedir. Ayrıca ağaç, ayna, 1şık, öğrenci ve sanatçı metaforları ikişer öğretmen adayı tarafından oluşturulmuştur. Bu metaforlara birer örnek aşağıdaki şekildedir.

“Matematik ögretmeni güneş gibidir; çünkü etrafindakileri aydınlatır.” (OMÖA40)

"Matematik öğretmeni ă̆aç gibidir; çünkü donanımı arttıkça ă̆aç gibi boyu uzar, kökleri uzar. Yani matematik öğretmeninin bilgileri, öğreneceği şeyler hep vardır. Sınırsız büyür birikimi. Bu birikim arttıkça yerinde daha da sağlamlaşır. Matematik ögretmeni ă̆aç gibi suda beslenir ve daha da gelişir." (OMÖA38)

"Matematik öğretmeni ayna gibidir; çünkü kendi bildiklerini öğrencilerine yansıtır." (OMÖA4)

“Matematik ögrretmeni ışık gibidir; çünkü herkese yol gösterir.” (OMÖA2)

"Matematik ögrretmeni öğrenci gibidir; çünkü hiçbir zaman "ben oldum” dememeli, hayatı boyunca araştırmall, öğrenmeli, matematik okyanusundan bir damla daha alabilmeye ve öğrendiklerini tıpk kendisi gibi olan ögrencilerine öğretmeye adamalıdır kendini." (OMÖA29)

"Matematik ögrretmeni sanatçı gibidir; çünkü farklı bakış açılarıyla düşünmeyi ögretir." (OMÖA22)

Tablo 3'e göre, diğer 38 metaforun birer öğretmen adayı tarafından oluşturulduğu görülmektedir. Bu metaforlardan bazıları; kâşif, kullanma kılavuzu, kroki, mum ve harita şeklindedir. Bu metaforlar ve gerekçeleri ile ilgili örnekler aşağıda sunulduğu gibidir.

"Matematik ögrretmeni kâşif gibidir; çünkü her çocuk keşfedilmeyi bekleyen bir evrendir.” (OMÖA6)

"Matematik öğretmeni kullanma kllavuzu gibidir; çünkü matematiği nasıl anlayacă̆ımızı, günlük yaşamdaki matematik problemlerini çözmemizi ve anlamlandırmamızı sağlar." (OMÖA23)

"Matematik öğretmeni kroki gibidir; çünkü bize nereye varmamı gerektiği hakkında bilgi verir." (OMÖA32) 
“Matematik öğretmeni mum gibidir; çünkü ışı saçtıkça etrafı aydınlatır." (OMÖA50)

“Matematik öğretmeni harita gibidir; çünkü doğruya giden yolu gösterir." (OMÖA55)

\subsection{Dördüncü Alt Problem ile İlgili Bulgular}

Dördüncü ve son araştırma problemi, "OMÖA'nın matematik ögretmeni kavramı ile ilgili oluşturdukları metaforlar, hangi kavramsal kategoriler altında toplanmaktadır?" şeklinde ele alınmıştır. Buradaki amaç, öğretmen adaylarının matematik öğretmenini ne şekilde gördüklerinin daha detaylı olarak ortaya konmasını sağlamaktır. Bu kapsamda yapılan değerlendirme sonucunda, matematik öğretmeni kavramına ilişkin üretilen metaforların altı tane kavramsal kategori altında toplandığı bulgusu elde edilmiștir. Bu kavramsal kategoriler; yol gösterici/rehber ( $\mathrm{f}=18$ ), davranıș ( $\mathrm{f}=14)$, öğretici/yetiștirici $(\mathrm{f}=10)$, sevme-sevmeme $(\mathrm{f}=4)$, öğrenen $(\mathrm{f}=3)$ ve diğer $(\mathrm{f}=10)$ şeklindedir. İlk kategori olan yol gösterici/rehber ile ilgili elde edilen bulgular aşağıdaki şekildedir.

\section{Yol Gösterici/Rehber}

Öğretmen adayları tarafindan "yol gösterici/rehber" kavramsal kategorisi ile ilgili 13 farklı, toplam 18 metaforun üretildiği bulgusu elde edilmiştir. Bu metaforlar aşağıda Tablo 4'te sunulmuştur.

Tablo 4: Yol Gösterici/Rehber

\begin{tabular}{llllll}
\hline No & Metafor & f & No & Metafor & f \\
\hline 1 & Pusula & 4 & 8 & Budama makası & \\
2 & Iş1k & 2 & 9 & Kalem & \\
3 & Güneş & 2 & 10 & Kitap & \\
4 & Kullanma kılavuzu & 1 & 11 & Mum & \\
5 & El feneri & 1 & 12 & İpucu & \\
6 & Kroki & 1 & 13 & Harita & \\
7 & Navigasyon & 1 & & & $\mathbf{1 8}$ \\
\hline Toplam & & & & & \\
\hline
\end{tabular}

Tablo 4'e göre, dört öğretmen adayı tarafından pusula metaforu, ikişer öğretmen adayı tarafindan ise ışık ve güneş metaforları yazılmıştır. Diğer metaforlar ise birer öğretmen adayı tarafından belirtilmiştir. Metaforların açıklamaları incelendiğinde, matematik öğretmeninin, yol gösterici, rehberlik eden yönüne odaklanıldığı belirlenmiştir. Örneğin;

"Matematik öğretmeni, pusula gibidir; çünkü yön, yol gösterir. Öğrencinin bilgiye ulaşması için rehber olur." (OMÖA56)

“Matematik öğretmeni, ışılk gibidir; çünkü herkese yol gösterir.” (OMÖA2)

"Matematik öğretmeni, güneş gibidir; çünkü etrafindakileri aydınlatır." (OMÖA40)

"Matematik ögrretmeni, ipucu gibidir; çünkü ögrrencinin doğru şekilde çıkışa ulaşmasinda cesaret verir, yolunu aydinlatır ve rehberlik eder." (OMÖA51)

2. Davranış

Ortaokul matematik öğretmeni adayları tarafından "davranış" kavramsal kategorisi ile ilişkili 13 farklı, toplam 14 metaforun olduğu görülmektedir. Elde edilen bulgular aşağıda Tablo 5’te sunulmuş̧ur. 
Tablo 5: Davranış

\begin{tabular}{llllll}
\hline No & Metafor & f & No & Metafor & f \\
\hline 1 & Ayna & 2 & 8 & Danışman & 1 \\
2 & Renk & 1 & 9 & Arı & 1 \\
3 & Ăgaç & 1 & 10 & Sanatçı & 1 \\
4 & Kâşif & 1 & 11 & Renkli kalemler & 1 \\
5 & Güneş & 1 & 12 & Çocuk bakıcısı & 1 \\
6 & Ressam & 1 & 13 & Çikolata kutusu & 1 \\
7 & Pamuk şeker & 1 & & & \\
\hline Toplam & & & & & $\mathbf{1 4}$ \\
\hline
\end{tabular}

Tablo 5'e göre, ayna metaforu iki öğretmen adayı tarafından yazılırken diğer metaforlar birer öğretmen adayı tarafından yazılmıştır. Bu metaforlar incelendiğinde, adayların matematik öğretmeninin nasıl davranması gerektiğine vurgu yaptıkları belirlenmiştir. Örneğin;

"Matematik öğretmeni, ayna gibidir; çünkü kendi bilgi, birikim ve kültürünü ögrrenciye yansitmalıdır.” (OMÖA13)

"Matematik öğretmeni, ăgaç gibidir; çünkü yeri geldiğinde yaslanacă̆ımız bir omuzdur. Yıllar geçtikçe olgunlaşan ve nefes aldıran biridir.” (OMÖA5)

“Matematik öğretmeni, pamuk şeker gibidir; çünkü her öğretmen gibi o da yumuşacık olmall, ögrencilerini sevmelidir ve tatlıdır." (OMÖA15)

"Matematik öğretmeni, danışman gibidir; çünkü bir öğretmen sadece matematik ya da farklı bir ders anlatmamalıdır. Aynı zamanda her ögrencinin derdini, sevincini, üzüntüsünü paylaşabileceği biri olmalıdır.” (OMÖA27)

\section{3. $\quad$ Öğretici/Yetiștirici}

Katılımcıların "öğretici/yetiştirici” kavramsal kategorisi ile ilgili olarak yedi farklı, toplam 10 metafor ürettikleri görülmüştür. Bu metaforlardan bahçıvan, dört öğretmen adayı tarafindan yazılırken uzay mekiği, makas ve yapıştırıcı, sanatçı, toprak, şelale ve anne metaforları birer öğretmen adayı tarafından yazılmıştır. Metaforların açıklamaları incelendiğinde, matematik öğretmeninin öğreten ve yetiştiren yönüne odaklanıldı ̆̆ belirlenmiştir. Örneğin;

"Matematik ögrretmeni, bahçıvan gibidir; çünkü bir sürü ögrrenciyi bir çiçek gibi yetiştirir.” (OMÖA24)

“Matematik ögrretmeni, sanatçı gibidir; çünkü farklı bakış açılarlyla düşünmeyi öğretir.” (OMÖA22)

\section{Sevme-Sevmeme}

Öğretmen adaylarının "sevme-sevmeme" kavramsal kategorisi ile ilgili dört farklı metafor yazdıkları bulgusuna ulaşılmıştır. Bu metaforlar; brokoli, kı1, kalemlik ve eşit kollu terazi şeklindedir. Metaforların açıklamaları incelendiğinde, matematik öğretmeninin ya sevildiği ya da sevilmediğine yönelik ifadelerin olduğu görülmüştür. Örneğin;

"Matematik ögrretmeni, brokoli gibidir; çünkü ya çok sevilir ya da nefret edilir. Bu hissiyatın oluşup oluşmaması da öğretmenin elindedir. Bir matematik öğretmeni, ögrencisinin kalbine girebildiği müddetçe sevilir. " (OMÖA9) 
"Matematik öğretmeni, eşit kollu terazi gibidir; çünkü ögrretmenin durumuna göre, öğrenciler matematiği ya aşırl severler ya da matematikten nefret ederler. Belki bu tüm dersler için böyle ama matematikte daha büyük bir etken." (OMAÖ26)

\section{5. Öğrenen}

Öğretmen adaylarının "öğrenen” kavramsal kategorisi ile ilgili iki farklı, toplam üç metafor ürettikleri belirlenmiştir. Bu metaforlar öğrenci ve ağaçtır. Metaforların açıklamaları incelendiğinde, adayların, matematik öğretmenin de bir öğrenci olduğunu ve sürekli öğrenmesi gereken şeylerin olduğunu belirttikleri bulgusu elde edilmiştir. Örneğin;

"Matematik ögretmeni, öğrenci gibidir; çünkü hiçbir zaman ben oldum dememeli, hayatı boyunca araştırmall, ögrenmeli, matematik okyanusundan bir damla alabilmeye ve ögrendiklerini tıpkı kendisi gibi olan öğrencilerine ögrretmeye adamalıdır kendini.", (OMÖA29)

"Matematik öğretmeni, ă̆aç gibidir; çünkü donanımı arttıkça ă̆aç gibi boyu uzar. Matematik ögretmeninin bilgileri, öğreneceği şeyler hep vardır. Sinırsız büyür birikimi. Bu birikim arttıkça yerinde daha da sağlamlaşır. Matematik öğretmeni de ă̆aç gibi sudan beslenir ve daha da gelişir. " (OMÖA38)

\section{Dĭ̌ger}

Öğretmen adayları tarafından üretilen 10 tane metaforun herhangi bir kategori ile ilişkisi kurulamamıştır. Bu sebeple bu metaforlar, "diğer" kavramsal kategorisi altında toplanmıştır. Bu metaforlar; diğer öğretmenler, yapboz parçası, illüzyonist, hesap makinesi, gezegenler, aşçı, Atatürk olmak, su tesisatçısı, kombin ve boya kalemi şeklindedir. Açıklamaları incelendiğinde, her bir metaforun farklı noktaya odaklandığı belirlenmiştir. Örneğin;

“Matematik ögretmeni, illüzyonist gibidir; çünkü matematik problemi çözmek sihir ister.” (OMAÖ28)

"Matematik öğretmeni, aşçı gibidir; çünkü yemek yapmayı herkes bilir ama asıl üstat aşçıdır. Herkes matematik ögrettiğini düşünür ama asıl üstat matematik ögretmenidir." (OMAÖ42)

\section{SONUC, TARTISMA VE ÖNERILER}

$\mathrm{Bu}$ araştırmada, ortaokul matematik öğretmeni adayları tarafından matematik kavramının açıklanabilmesi için 47 farklı metaforun üretildiği ve daha sık tekrar edilen metaforların; bina, puzzle ve su metaforları olduğu görülmüştür. Bu metaforlar aracılığıyla, adaylar tarafından matematiğin; "evrendeki parçaları birleştirerek ihtiyacımız olan yapıları inşa etmek” olarak algılandı̆̆ ortaya konmuştur. Noyes (2006) çalışmasında, matematiğin bu çalışmada elde edilen metaforlardan farklı metaforlar ile temsil edildiği sonucuna ulaşmış olup üretilen metaforlar bağlamında çalışmaların paralellik göstermediği görülmektedir. Bu durumun çalışmaların farklı kültürlerde gerçekleştirilmesinden kaynaklı olabileceği düşünülmektedir. Yapılan bu araştırmada evrendeki parçaları birleștirerek ihtiyacımız olan yapıları inşa etmek sonucunun hayat ile ilişkili olduğu göz önüne alındığında ise alanda yapılan bir çok çalışma (Brady ve Winn, 2014; Çalışıcı ve Özçakır-Sümen, 2019; Demirkol ve Ergin, 2017; Evren-Yapıcıoğlu ve Korkmaz, 2019; Güler vd., 2012; Güner, 2013; Kuzu vd., 2018) ile paralellik gösterdiği ortaya çıkmıştır. Bu paralellikten yola çıkılarak, matematiğin günlük yaşamdaki öneminin göz ardı edilmemesi gerektiği ve öğretmenlerin derslerinde günlük yaşamda yer alan matematiği öğrencilerine fark ettirmeleri önerilmektedir. Örneğin; süt kutularının dikdörtgenler prizması, bazı gazlı içeceklerin silindir şeklindeki kaplarda olduğu yönündeki örneklendirmelerle matematiğin yaşamın içinde yer aldığg farkındalı̆̆ı sağlanabilir. 
Araştırmadan elde edilen diğer sonuç ise ortaokul matematik öğretmeni adayları tarafından üretilen metaforların farklı kavramsal kategorilerle ilişkilendirilmesidir. Bu kavramsal kategoriler; içerik/yapı, duruma görelik, sonsuzluk, yol gösterici/rehber, zevk/eğlence ve her şeyde/yerde olarak belirlenmiştir. Bu kategorilerde yer alan metaforların açıklamalarından elde edilen sonuçlar ise aşağıdaki şekildedir. Ortaokul matematik öğretmeni adaylarına göre matematik;

1. Birbiriyle bağlantılı farklı konuları içermektedir.

2. Çeşitli çözüm yollarının yanında tek bir sonuca sahiptir.

3. Temelinin sağlam atılması gerekmektedir.

4. Düşünme gerektiren aşamalı bir döngüdür.

5. Ucu bucağı olmayan sonsuz bilgiler içermektedir.

6. Her konusu ayrı zevklidir.

7. Düşünürken eğlenmeyi sağlar.

8. Duruma göre değişmektedir.

9. Hayatın her yerindedir ve her şekilde kullanılmaktadır şeklindedir.

Güler vd. (2012) çalışmalarında, öğretmen adayları tarafından matematiğin, yol gösterici, gereksinim, bakış açısı, sonsuzluk ve hayatın kendisi kavramsal kategorileri ile açıklandığı sonucunu elde etmişlerdir. Çalışmalar yol gösterici ve sonsuzluk kavramsal kategorileri çerçevesinde paralellik göstermektedir. Güner (2013) ise matematiğin; matematik hayatın kendisidir, matematik zevkli bir uğraştır, matematik hayatı kolaylaştırır ve matematik hayatı zorlaştırır kategorileri altında ele alındığını belirlemiştir. Matematiğin zevkli bir uğraş olması bağlamında çalışmaların paralellik gösterdiği görülmektedir. Zevkli ifadesi hoşa giden, beğenilen anlamına gelmektedir (TDK, 2021f). Bu sebeple de elde edilen bu sonucun öğretmen adaylarının matematiğe yönelik olumlu algılara sahip olduğunu gösterdiği düşünülmektedir. $\mathrm{Bu}$ da öğretimini yapacak oldukları matematiği, zevkle ve severek öğreteceklerinin bir kanıtı olarak görülebilir. Erdoğan vd.'nin (2014) çalışması ile bu çalışma eğlence, yol gösterici ve tek bir sonucunun olması kategorilerinde paralellik göstermektedir. Bu çalışma, eğlence kategorisi bağlamında ise Kuzu vd.'nin (2018) çalışması ile paraleldir. Nitekim bir kez daha matematiğin eğlenceli olması ve yol gösterici özelliği noktalarında çalışmaların benzerlik gösterdiği görülmektedir. Hayat/yaşam ile ilişkili matematik ve temellerini doğadan alan matematik kategorileri kapsamında ise Evren-Yapıcıoğlu ve Korkmaz'ın (2019) çalışması ile bu çalışmanın ortak noktaları olduğu görülmektedir.

Ortaya konan tüm bu kavramsal kategorilerin matematiği anlamamızda ve ona yönelik algıları ortaya çıkarmada bir yol gösterici olduğu göz önüne alınarak, çalışma grubunu öğretmen adaylarının oluşturduğu, matematiğe yönelik düşünce ölçeğinin geliştirilmesine yönelik çalışmalar yapılabilir. Ölçek maddelerinin yazılmasında üretilen metaforlar ve kavramsal kategoriler dikkate alınabilir. Geliştirilen ölçek kullanılarak öğretmen adaylarının matematiğe yönelik düşünceleri ortaya konabilir. Bu düşüncelerden yola çıkılarak matematiğin, öğretmen adaylarına göre anlamları tespit edilebilir. Bu da matematiğin daha derin bir şekilde anlaşılmasında yol gösterici olabilir.

Araştırmadan elde edilen bir diğer sonuç; ortaokul matematik öğretmeni adayları tarafından matematik öğretmeni kavramının farklı metaforlar ile ifade edilmesidir. Ön plana çıkan metaforlar; bahçıvan, pusula ve güneş şeklindedir. Bu metaforlar, adayların matematik öğretmenini; “öğrencilerini iyi bir şekilde tanıyarak öğretim yapan ve onları aydınlatan bir yol gösterici” olarak algıladıklarını göstermiştir. Cerit'in (2008) araştırmasında da öğretmen kavramına yönelik olarak tek bir metafora odaklanılmadığg ortaya konmuştur. Oluşturulan metaforlardan bazıları; melek, bakıcı, bilgi kaynağ1 ve dağıtıcı, arkadaş, üretici, gardiyan, bahçıvan ve rehber şeklindedir. Yılmaz vd. (2013) farklı branşlarda öğrenim görmekte olan öğretmen adaylarının, öğretmen kavramı ile ilgili en çok anne-baba, bahçıvan, anne ve rehber metaforlarını ürettikleri sonucuna erişmişlerdir. Benzer şekilde Aydın ve Pehlivan (2010), Gurrero ve Villamil (2002) ile Saban, Koçbeker ve Saban (2006) da çalışmalarında, öğretmen kavramına yönelik olarak birden fazla metaforun oluşturulduğu sonucuna ulaşmışlardır. Koç, sinema-tiyatro 
yönetmeni, senfoni yönetmeni, güneş, ebeveyn ve pusula ile ağaç metaforları ulaşılan bu metaforlara örnektir. Görüldüğü üzere üretilen metaforlar bu araştırma kapsamında matematik öğretmenine yönelik üretilen metaforlar ile paralellikler göstermektedir. Özellikle anne veya ebeveyn metaforunun çalışmalarda ortaya çıkması, öğrencilerin öğretmenleri anneleri ile özdeşleştirdiklerinin bir göstergesi olabilir. Elbette araştırma öğretmen adayları ile gerçekleştirilmiş durumdadır ki onlar da henüz hem öğrenci konumundadırlar bu sebeple bu metaforu üretirken kendi deneyimlerine odaklanmış olabilirler. Ayrıca ailelerimizde eğitim-öğretim işi ile daha çok annelerin ilgilenmesi bu metaforların ortaya çıkmasına sebep olmuş olabilir. Bu bağlamda da annelerin matematik öğretimi bağlamında etkilerinin incelendiği çalışmalar yapılabilir.

Ayrıca yürütülen bu araştırma da dahil olmak üzere tüm bu çalışmalarda, matematik öğretmeni ile ilgili birden fazla metaforun oluşturulduğu sonucu elde edilmiştir. Bu durumun nedeni, bir kavramı bireylerin kendi bilgi, deneyim ve tecrübeleri doğrultusunda tanımlamaya çalışmaları olabilir. İçinde yaşadığımız çevre ve onun uzantısı olan kültür, kendimizi ifade etmeyi dolasıyla da herhangi bir kavrama yönelik algılarımızı etkilemektedir denilebilir. Bu sebeple de zihinlerimizde farklı metaforların canlanması olasıdır. Ayrıca geçmiş deneyimlerimiz de, matematik öğretmenleri ile yaşantılarımız da onu ifade etme biçimimizi etkiliyor olabilir. Bu durumu Çırak-Kurt ve Yıldırım (2020), öğretmenlik mesleğinin özveri mesleği olduğunu ve öğretmenlerin öğrencilere kılavuzluk ederken öğrenci davranışlarını şekillendirdiklerini belirterek açıklamaktadırlar. Bu açıklamadan da yola çıkılarak, çalışmaya katılan öğretmen adaylarının, kendi matematik öğretmenlerini düşünerek metafor oluşturmuş olabilecekleri söylenebilir. Bu sebeple de matematik öğretmeninin tanımlandığı, yine metaforlar ile ifade edildiği çalışmalar yapılabilir. Örneğin; benzer şekilde ortaokul matematik öğretmeni adaylarının çalışma grubu olduğu bir araştırmada, adaylardan, şu ana kadar karşılaşmış oldukları matematik öğretmenlerini tanımlamaları istenebilir. Bu tanımlamalarda; matematik öğretmenim otoriterdi, dersi sıkıcı işlerdi, dersi zevkli hale getirmek için oyunlar oynatırdı vb. gibi ifadelere yer vermeleri istenebilir. Daha sonra yine matematik öğretmenini metafor ile ortaya koymaları söylenebilir. Böylece matematik öğretmeni ile ilgili yazılan ifadelerle bu kavrama yönelik atfedilen metaforların karşılaştırması yapılabilir.

Araştırmadan elde edilen son sonuç ise ortaokul matematik öğretmeni adaylarına göre matematik öğretmeni kavramının altı farklı kavramsal kategori altında toplandığıdır. Bu kategoriler; davranış, yol gösterici/rehber, öğrenen, sevme-sevmeme, öğretici/yetiştirici ve diğer şeklindedir. Bu kavramsal kategorilerde yer alan metaforların açıklamalarından elde edilen ve çalışmaya katılan ortaokul matematik öğretmeni adaylarına göre matematik öğretmeni ile ilgili sonuçlar; matematik öğretmeni; i) yol göstericidir, rehberdir, ii) öğrenendir, iii) ya sevilir ya sevilmez ve iv) öğretendir, yetiştirendir şeklindedir.

Güler, Öçal ve Akgün (2011), matematik öğretmenine yönelik oluşturulan metaforların, danışman, tanıdık biri, yabancı, çalışkan, düzenleyici, bilgi sağlayıcı, karmaşık, sonsuzluk-mükemmel ve birleştirici olmak üzere dokuz farklı kavramsal kategoride açıklandığı sonucunu elde etmiş̧lerdir. Çalışmalardaki danışman kategorisi yol gösterici-rehber kategorisi ile paralellik gösterirken bilgi sağlayıc1 kategorisi öğreten-yetişiren kategorisi ile paralellik göstermektedir. Bu bağlamda farklı katılımcıların matematik öğretmeninin danışman-rehber-yol gösterici olması ve öğreten-bilgi sağlayıcı özelliklerinde hem fikir oldukları söylenebilir. Geleceğin öğretmenleri olacak adayların, bu özellikleri kendilerinde görüp görmedikleri ise aralarından gönüllü olanlarla yapılacak yarı-yapılandırılmış görüşmelerle ortaya çıkarılabilir.

Yılmaz vd. (2013) de çalışmalarında, öğretmen kavramının; yol gösterici öğretmen, şekillendirici öğretmen, statüsü olmayan öğretmen, bilgi kaynağı olan öğretmen, esnek öğretmen, kutsal bir iş yapan öğretmen ve model olan öğretmen olarak yedi farklı kavramsal kategoride açıklanmaya çalışıldığı sonucuna ulaşmışlardır. Benzer şekilde Saban, Koçbeker ve Saban (2007) da öğretmenlerin bilgi sağlayıcı bireyler olarak algılandığı sonucuna ulaşmışlardır. Bu çalışmalarda ulaşılan sonuçlarla da bu araştırmadan elde edilen sonuçların paralellik gösterdiği görülmektedir. Özellikle matematik öğretmeninin yol gösterici ve yetiştirici olma ile bilgi kaynağı olarak görülme özelikleri açılarından 
çalışmaların benzerlik gösterdiği belirlenmiştir. Cerit (2008) öğretmenlerin bilgi kaynağı olarak görülmesinin eğitim etkinliklerinin bilgi aktarım odaklı olduğunun bir göstergesi olduğunun düşünülmesi gerektiğini belirtmektedir. Bu bağlamda bu araştırmadan elde edilen sonucun da benzer noktaya işaret ettiği ve eğitim sistemimizin bilgi aktarma odaklı devam etmekte olduğu söylenebilir. Oysa Cerit'in (2008) de belirttiği gibi nitelikli bir eğitim için kaliteli öğretmenlerin var olması gerekmektedir. Öğrencilerin öğrenmelerine yardımcı olurken onların sahip oldukları yetenekleri geliştiren, bilgiyi hazır olarak vermek yerine bilgiye ulaşma yollarını gösteren ve ulaşılan bu bilgiyi kullanma becerisini kazandıran öğretmenlerin, geleceğin bireylerini yetiştirebilecekleri ifade edilmektedir. Bu sebeple de rehberlik ederek bilginin kaynağına ulaşmayı, ulaşılan bilgiyi işlemeyi ve kullanmayı öğreten öğretmenlerin yetiştirilmesinin önemli olduğu düşünülmekte ve ülkemiz eğitim fakültelerinde belirtilen özelliklere sahip öğretmenlerin yetiştirilmelerine yönelik çalışmaların yapılması önerilmektedir. Örneğin; bilgi aktarıcı yerine rehber olan öğretmenler yetiştirilmesi için çalışmalar yaptırılabilir. Öğretmen adaylarından sunuş yoluyla ders anlatmalarının yanı sıra çeşitli yöntem ve teknikleri (işbirliğine dayalı öğretim, oyunların kullanımı, teknoloji desteği vb. gibi) kullanmalarına yönelik yönlendirmelerde bulunulabilir. Tüm çalışmalarda yer alan kategoriler ve yukarıda ortaya konan matematik öğretmeni ile ilgili dört ifade çerçevesinde ise, matematik öğretmenine yönelik bir düşünceler anketi geliştirilebilir. Bu anket yardımı ile öğrencilerde matematik öğretmenine yönelik var olan algılar belirlenebilir.

Araştırmanın uygun örnekleme ile yapılmış olması bir sınırlılık olarak görülebilir. Bu sınırlılığın ortadan kaldırılabilmesi için farklı üniversitelerde öğrenim görmekte olan OMÖA ile araştırma tekrar edilebilir. Böylece farklı üniversitelerde öğrenim gören adayların algılarını da karşılaştırma firsatı yakalanmış olunur. Araştırma sadece dördüncü sınıfta öğrenim gören adaylar ile yürütülmüştür. Bu sebeple de katılımcı sayısı azdır. Katılımcı sayısının az olması ise bir sınırlılık olarak değerlendirilebilir. $\mathrm{Bu}$ sınırlılı̆̆ yinelenebilir. Matematiğin temellerinin ilkokulda atıldığı göz önüne alınırsa sınıf öğretmeni adayları ile araştırma yeniden gerçekleştirilebilir. Karşılaştırma yapmak adına ise farklı branşlarda öğrenim gören adaylarla benzer çalışmalar yürütülebilir. Ayrıca öğrencilerin matematiği ve matematik öğretmenini algılayış biçimleri ilkokuldan itibaren araştırılarak matematiğe yönelik bakış açıları tespit edilebilir.

\section{Etik Kurul Onay Bilgileri}

Bu çalışmada 2020 yılı ve öncesi verileri kullanılmış olup, çalışma süresince etik ilkelere dikkat edilmiştir. $\mathrm{Bu}$ ilkeler çerçevesinde katılımcı gönüllülüğü esas alınarak onları tanıtıcı bilgiler gizli tutulmuş ve veriler sadece bu bilimsel araştırmada kullanılmıştır.

\section{KAYNAKÇA}

Akdemir, Ö. (2006). İlköğretim Öğrencilerinin Matematik Dersine Yönelik Tutumları ve Başarı Güdüsü, (Yayımlanmamış Yüksek Lisans Tezi), (Danışman: Yrd. Doç. Dr. Uğur Altınay), İzmir: Dokuz Eylül Üniversitesi Eğitim Bilimleri Enstitüsü.

Aristo (2008). Poetika. İstanbul: Remzi Kitabevi.

Aydın, İ. S. ve Pehlivan, A. (2010). Türkçe Öğretmeni Adaylarının “Öğretmen” ve “Öğrenci” Kavramlarına İlişkin Kullandıkları Metaforlar. Turkish Studies International Periodical for the Languages, Literature and History of Turkish or Turkic, 5(3), 818-842.

Brady, K. ve Winn, T. (2014). Using Metaphors to Investigate Pre-Service Teachers Primary Teachers' Attitudes towards Mathematics. Double Helix, 0(2), 1-10.

Cerit, Y. (2008). Öğretmen Kavramı ile İlgili Metaforlara İlişkin Öğrenci, Öğretmen ve Yöneticilerin Görüşleri. Türk Ĕgitim Bilimleri Dergisi, 6(4), 693-712.

Cohen, L. ve Manion, L. (1989). Research Methods in Education. London: Routledge.

Creswell, W. J. (2007). Qualitative Inquiry and Research Design-Choosing among Five Approaches, (2nd ed.). London: Sage Publications.

Cropley, A. (2002). Qualitive Research Methods: An Introduction for Students of Psychology and Education. Zinatne: University of Latvia. 
Çalışıcı, H. ve Özçakır-Sümen, Ö. (2019). Matematik Öğretmen Adaylarının Matematiğe Yönelik Algıları: Bir Metafor Çalışması. International Journal of Educational Studies in Mathematics, 6(3), 108-123.

Çekici, E. ve Yıldırım, H. (2011). Matematik Eğitimi Üzerine Bir İnceleme. Marmara Üniversitesi I.B.B.F. Dergisi, XXXI(II), 175-196.

Çelik, H. ve Çakır, E. (2015). The Examination of Metaphoric Perception on the Effects of Heat on Substance. International Online Journal of Educational Sciences, 7(2), 244-264.

Çırak-Kurt, S. ve Yıldırım, İ. (2020). İlköğretim Matematik Öğretmenleri ile Öğretmen Adaylarının Çeşitli Kavramlara İlişkin Metaforik Algıları. Pamukkale Üniversitesi Eğitim Fakültesi Dergisi, 0(48), 174-198.

Dede, Y. ve Argün, Z. (2004). Öğrencilerin Matematiğe Yönelik İçsel ve Dışsal Motivasyonlarının Belirlenmesi. Eğitim ve Bilim, 29(134), 49-54.

Demirkol, N. ve Ergin, D. E. (2017). Matematik Öğretmen Adaylarının Matematik ve Matematik Öğretmenliği Metaforik Algıları. IV. International Balkan and Near Eastern Social Sciences Congress Series, IV. IBANESS Kongreler Serisi Tam Metin Kitabı (08-09 Nisan 2017) İçinde (s. 713-721). Bulgaria: University of Agribusiness and Rural Development.

Erdoğan, A.; Yazlık, O. D. ve Erdik, C. (2014). Mathematics Teacher Candidates' Metaphors about the Concept of "Mathematics". International Journal of Education in Mathematics, Science and Technology, 2(4), 289-299.

Evren-Yapıcıŏglu, A. E. ve Korkmaz, N. (2019). Öğretmen Adaylarının Fen ve Matematiğe Yönelik Algılarının Belirlenmesi: Metafor Çalışması. Akdeniz Eğitim Araştırmaları Dergisi, 13(29), 400420.

Forcenville, C. (2002). The Identification of Target and Source in Pictorial Metaphors. Journal of Pragmatics, 0(34), 1-14.

Guerreo, M. C. M. ve Villamil, O. S. (2002). Metaphorical Conceptualizations of ELS Teaching and Learning. Language Teaching Research, 6(2), 95-120.

Güler, G.; Öçal, M. F. ve Akgün, A. (2011). Pre-service Mathematics Teachers' Metaphors about Mathematics Teacher Concept. Procedia Social and Behavioral Sciences, 0(15), 327-330.

Güler, G.; Akgün, L.; Öçal, N. F. ve Doruk, M. (2012). Matematik Öğretmeni Adaylarının Matematik Kavramına İlişkin Sahip Oldukları Metaforlar. Eğitim ve Öğretim Araştırmaları Dergisi, 1(2), 25-29.

Güner, N. (2013). Öğretmen Adaylarının Matematik Hakkındaki Oluşturdukları Metaforlar. E-Journal of New World Science Academy, 8(4), 428-440.

Halmos, P. R. (1980). The Hearts of Mathematics. The American Mathematical Monthly, 87(7), 519-524.

Kuzu, O.; Kuzu Y. ve Sivacı, S. Y. (2018). Öğretmen Adaylarının Matematik Kavramına Yönelik Tutumları ve Metafor Algıları. Çukurova Üniversitesi Ĕgitim Fakültesi Dergisi, 47(2), 897-931.

Lakoff, G. ve Johnson, M. (2005). Metaforlar: Hayat, Anlam ve Dil, (Çeviren: G. Y. Demir). İstanbul: Paradigma.

Miles, M. B. ve Huberman, A. M. (1994). Qualitative Data Analysis. Thousans Oaks, CA: Sage Publications.

Noyes, A. (2004). (Re) Producing Mathematics Educators: A Sociological Perspective. Teaching Education, 15(3), 243-256.

Noyes, A. (2006). Using Metaphor in Mathematics Teacher Preparation. Teaching and Teacher Education, 0(22), 898-909.

Oksanen, S.; Portaankorva-Koivisto, P. ve Hannula M. S. (2014). Teacher Metaphors-Differences Between Finnish In-Service and Pre-Service Mathematics Teachers. (Eds. P. Liljedahl, S. Oesterle, C. Nicol ve D. Allan). Proceedings of the Joint Meeting of PME 38 and PME-NA 36 İçinde (s. 361-368). Vancouver, Canada: PME.

Patton, M. Q. (2002). Qualitative Research \& Evaluation Methods, (3rd ed.). London: Sage Publications.

Perry, C. ve Cooper, M. (2001). Metaphors Are Good Mirrors: Reflecting on Change for Teacher Educators. Reflective Practice, 2(1), 41-52.

Ravid, R. (1994). Practical Statistics for Educators. New York: University Press in America.

Saban, A. (2004). Giriş Düzeyindeki Sınıf Öğretmeni Adaylarının “Öğretmen” Kavramına İlişkin İleri Sürdükleri Metaforlar. Türk Ĕ̈itim Bilimleri Dergisi, 2(2), 131-155. 
Saban, A. (2009). Öğretmen Adaylarının Öğrenci Kavramına İlişkin Sahip Oldukları Zihinsel İmgeler. Türk Eğitim Bilimleri Dergisi, 7(2), 281-326.

Saban, A.; Koçbeker, B. N. ve Saban, A. (2006). Öğretmen Adaylarının Öğretmen Kavramına İlişskin Algılarının Metafor Analizi Yoluyla İncelenmesi. Kuram ve Uygulamada Eğitim Bilimleri, 6(2), 461-522.

Saban, A.; Koçbeker, B. N. ve Saban, A. (2007). Prospective Teachers' Conceptions of Teaching and Learning Revealed through Metaphor Analysis. Teaching and Teacher Education, 0(17), 123139.

Şahin, B. (2013). Öğretmen Adaylarının "Matematik Öğretmeni”, "Matematik" ve "Matematik Dersi" Kavramlarına İlişkin Sahip Oldukları Metaforik Algılar. Mersin Üniversitesi Eğitim Fakültesi Dergisi, 9(1), 313-321.

Taşpınar-Şener, Z.; Ünal, H. ve Aydın, H. (2016). Using Mteaphors to Investigate Pre-Service Secondary Mathematics Teachers' Perceptions of Mathematics and Mathematics Teacher Concepts. Anthropologist, 23(1,2), 291-302.

TDK (2021a). Matematik. https://sozluk.gov.tr/ adresinden 21.02.2021 tarihinde erişildi.

TDK (2021b). Metafor. https://sozluk.gov.tr/ adresinden 21.02.2021 tarihinde erişildi.

TDK (2021c). Bulmaca. https://sozluk.gov.tr/ adresinden 26.11.2021 tarihinde erişildi.

TDK (2021d). Güneş. https://sozluk.gov.tr/ adresinden 26.11.2021 tarihinde erişildi.

TDK (2021e). Işsk. https://sozluk.gov.tr/ adresinden 26.11.2021 tarihinde erişildi.

TDK (2021f). Zevkli. https://sozluk.gov.tr/ adresinden 20.07.2021 tarihinde erişildi.

Uçar, T. Z.; Pişkin, M.; Akkaş, N. E. ve Taşçı, D. (2010). İlköğretim Öğrencilerinin Matematik, Matematik Öğretmenleri ve Matematikçiler Hakkındaki İnançları. Eğitim ve Bilim, 35(135), 131144.

Umay, A. (2002). Öteki Matematik. Hacettepe Üniversitesi Eğitim Fakültesi Dergisi, 0(23), 275-281.

Yetim-Karaca, S. ve Ada, S. (2018). Öğrencilerin Matematik Dersine ve Matematik Öğretmenine Yönelik Algılarının Metaforlar Yardımıyla Belirlenmesi. Kastamonu Eğitim Dergisi, 26(3), 789800.

Yıldırım, A. ve Şimşek, H. (2008). Sosyal Bilimlerde Nitel Araştırma Yöntemleri. Ankara: Seçkin Yayıncilik.

Yılmaz, O. ve Altıntaş, G. (2018). 4. Sınıf Sosyal Bilgiler Dersi ‘Geçmişimi Öğreniyorum’ Ünitesindeki Geliştirme Düzeyi Kavramları Üzerine Öğrencilerin Geliştirdikleri Metaforlar. Kastamonu Ë̆itim Dergisi, 26(2), 613-619.

Yılmaz, F.; Göçen, S. ve Yılmaz, F. (2013). Öğretmen Adaylarının Öğretmen Kavramına İlişkin Algıları: Bir Metaforik Çalışma. Mersin Üniversitesi Eğitim Fakültesi Dergisi, 9(1), 151-164. 
